\title{
Un paisaje nuevo de lo posible. Hacia una conceptualización de la "ficción documental" a partir de Fotografías, de Andrés Di Tella
}

\section{Horne, Luz}

Resumen:

Una de las características más notorias de la literatura contemporánea es la ambivalencia en la definición de su estatuto ficcional. En muchos de los textos que se han publicado en las últimas décadas y que se califican como novelas o cuentos, la ficcionalidad resulta cuando menos- ambigua. Se trata de textos en los cuales la crónica, la autobiografía, la reflexión sobre el propio proceso de escritura o la escritura ensayística se entrelazan con fragmentos narrativos ficcionales, produciendo un cuestionamiento del estatuto de la ficción dentro de la literatura misma. En este artículo se afirma que el cine documental resulta un sitio propicio (un laboratorio), para pensar la transformación que sufre el concepto de ficción en el arte
Cuadernos del Centro de Estudios de Diseño y Comunicación N N 60

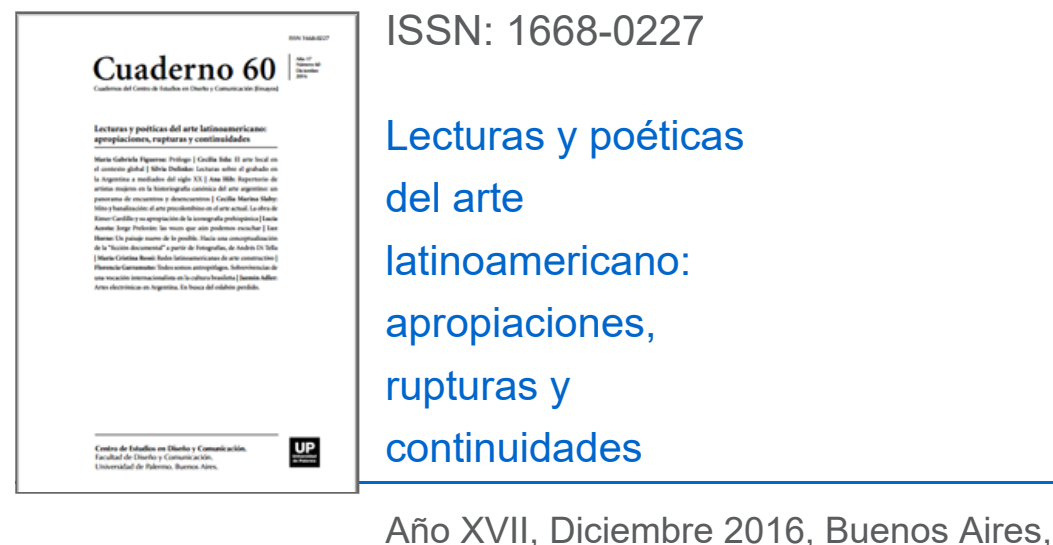

Argentina | 176 páginas

descargar PDF ver índice de la publicación

Ver todos los libros de la publicación

compartir en Facebook

contemporáneo. A partir del análisis del documental Fotografías (2006), de Andrés Di Tella, se indagan ciertos procedimientos en relación al modo en surge la ficción en su interior. La expectativa es que esta indagación sirva como base teórica para pensar las transformaciones que sufre la categoría de ficción no solo en el cine documental sino también, de un modo más amplio, en otras manifestaciones artísticas contemporáneas como, por ejemplo, en la literatura.

Palabras clave:

cine documental - arte contemporáneo - ficcionalidad ambigua - literatura - narrativa - crónica - autobiografía. 
$\left(^{*}\right)$ Profesora de Literatura en el Departamento de Humanidades de la Universidad de San Andrés. Obtuvo su PhD en Literatura brasileña e hispanoamericana en Yale University y su licenciatura en Filosofía en la Universidad de Buenos Aires. Se desempeñó como profesora en Northwestern University y en Cornell University. Cuenta con publicaciones en revistas reconocidas dentro del campo como Hispanic Review, Revista de Crítica Literaria Latinoamericana, Revista Iberoamericana y LASA-Forum. Su libro Literaturas reales. Transformaciones del realismo en la literatura latinoamericana contemporánea fue publicado en 2011 por Beatriz Viterbo Editora.

Con un título previo que luego modificó -“Viaje al país de mi madre”- Andrés Di Tella cuenta en Fotografías (2006) la historia de su madre, nacida en la India. La película se desarrolla a partir de dos ejes temporales. Por un lado, cuenta la migración de su madre desde la India a Buenos Aires, pasando por Londres y San Francisco, en donde la madre conoce a su padre argentino. Por el otro, desanda este camino en el presente, viajando él mismo desde Buenos Aires a la India con su mujer y su hijo y contando su propia relación con este territorio extranjero y al mismo tiempo familiar. En este trayecto, Di Tella (personaje de su propio film) pone en paralelo una narrativa familiar y una nacional, revelando en ambas una construcción ficcional y quitándoles naturalidad.

A partir del análisis de Fotografías, en este ensayo quisiera pensar en ciertos procedimientos propios del cine documental contemporáneo en relación al modo en que surge la ficción en su interior. La expectativa es que esta indagación sirva como base teórica para pensar las transformaciones que sufre la categoría de ficción no solo en el cine documental sino también, de un modo más amplio, en otras manifestaciones artísticas contemporáneas como en la literatura. Justamente, una de las características más notorias de la literatura contemporánea es la ambivalencia en la definición de su estatuto ficcional.

En muchos de los textos que se han publicado en las últimas décadas y que se califican como novelas o cuentos, la ficcionalidad resulta -cuando menos- ambigua. Basta pensar en algunos ejemplos de los más notorios, como Mario Bellatín, Bernardo Carvalho, Sergio Chejfec, Mario Levrero, Valeria Luiselli, João Gilberto Noll, Nuno Ramos, Tatiana Salem Levy o Alejandro Zambra para constatar -a pesar de las grandes diferenciasun territorio común en lo que concierne a esta ambigüedad. Se trata de textos en los cuales la crónica, la autobiografía, la reflexión sobre el propio proceso de escritura o la escritura ensayística se entrelazan con fragmentos narrativos ficcionales, produciendo un cuestionamiento del estatuto de la ficción dentro de la literatura misma1.

El cine documental, quisiera pensar aquí, resulta un lugar propicio para pensar esta transformación del concepto de ficción y para iluminar los procesos que ocurren dentro de la literatura. La definición misma de cine documental comporta desde sus orígenes una ambigüedad en su relación con la ficción y hasta se podría decir que esta ambigüedad es parte constitutiva misma del género2. Sin embargo, en las últimas décadas, la labilidad en la definición de cine documental se ha vuelto aún más prominente y hoy en día es casi un lugar común de la crítica hablar de los cruces entre documentalidad y ficción en el cine documental. La inclusión de una perspectiva subjetiva y ficcional en su seno ha dado a hablar de un "giro subjetivo o afectivo" (Michael Chanan, Alicia Lebow, Michael Renov), "performativo" (Nichols), o ha contribuido a subrayar la importancia de las películas caseras (Karen L. Ishizuka y Patricia Zimmermann) o autobiográficas (Renov). Estas lecturas han relativizado cierta asociación -quizás ingenua pero no por ello menos persistente- del cine documental con un 
discurso objetivo, informativo, expositivo o de autenticidad para colocarlo, en cambio, en un lugar que subraya la ambivalencia, la indefinición y la reflexión sobre la propia práctica artística. Tal como sugieren Michael Renov (2004) y Elisabeth Cowie (1999), a pesar de que haya una asociación histórica del documental con un discurso de orden científico, también se puede pensar el documental a través de una lógica del deseo o del inconsciente, no sólo por cierto "deseo de realidad" manifiesto, sino por el modo de asociación que se sigue en su narrativa.

A partir del análisis de Fotografías, entonces, quisiera poder iniciar una reflexión en la que no se trabaja sobre el cine y la literatura de un modo separado, sino sobre un tipo de narrativa o "ficción documental" que vincularía los dos medios y que se diferenciaría -no ya a partir de la especificidad mediática- de un cine de ficción o de una literatura de ficción, entendiendo el concepto de ficción dentro de una poética clásica3. Lo que me ocupará aquí con el análisis del film de Di Tella, entonces, no es únicamente la ambigüedad que se genera en el límite entre ficción y documental, sino el proceso y el modo en el cual surge la ficción dentro del documental mismo para -en un trabajo futuro- poder extender este proceso a otras formas narrativas, como la literatura contemporánea. Según argumentaré, el modo en el cual surge la ficción en Fotografías tiene cierta particularidad pues se genera de un modo íntimamente arraigado al documento: la ficción nace como una simulación de documentalidad. Es decir, el film se encuentra eventualmente con algo que no se puede mostrar: un documento perdido en el archivo o en el recuerdo. Es a partir de este hueco que la ficción nace. Frente a un tipo de arte basado en el valor del documento -en donde se produce una anticipación del sentido- o frente un arte memorialístico o confesional, que busca la expresión de un interior profundo y auténtico, en este tipo de narrativa documental (ya sea fílmica o textual), se rescata aquello que interrumpe la ambición objetiva; se subraya el valor de lo que se pierde o se olvida: una cierta disfuncionalidad, un resto improductivo, oscioso e indisciplinado. Es este exceso afectivo que se cuela como falla en el esfuerzo archivístico el que nos recuerda que, aunque es un documental, se trata, simultáneamente, de una ficción.

1. Moi, un noir

Fotografías emprende la relación con la cultura materna del director a través de un análisis exahustivo e íntimo. La película llega casi al colmo del subjetivismo y -respetando una marca cultural profundamente argentina- por momentos parece una sesión psicoanalítica hecha pública. Y esto no sólo por aquello que se dice (por el contenido) sino porque procede por pura asociación libre; ese es su método de construcción o su hechura. Así, el encanto y el interés del film está en cómo busca decir constantemente aquello que no estaba dicho, aquello que incluso parecía no querer ser dicho. En el caso del personaje que el propio Di Tella construye para sí mismo, lo no dicho aparece como una revelación acerca de su propia identidad: "soy negro, soy WOG" (Western Oriental Gentelman). Fotografías cuenta una anécdota que marca para Di Tella el momento en el cual se dio cuenta, cuando era chico, de que era "negro": jugando con otros niños en Londres, le dicen "fucking wog" y, sin saber lo que era la palabra, advierte las caras de asco de los otros niños y advierte que se trata de un insulto terrible. Luego, a modo de revelación, encuentra en un frasco de mermelada la imagen de un niño de color junto con la palabra "gellywag" y termina de corroborar su presentimiento4.

Una de las primeras cosas que llaman la atención de las notas que Di Tella incluye en el libro que acompaña la película y que la iluminan de un modo diferente, permitiendo una segunda lectura, es la insistencia en el 
problema racial5. El propio Di Tella afirma la necesidad de que este sea uno de sus ejes centrales: "Hablar lo más crudamente -lo más crudamente posible- de racismo, para que conserve algo de su impacto y no sea simplemente un tema" (Firbas - Meira Monteiro 2006, 127). Pero la manera de acercarse a este tema - el temano es el de la denuncia sino el de radicalizar el autoanálisis hasta mostrar que el racismo como estructura social es tan poderoso que incluso se aloja en el propio yo.

En primer lugar, Di Tella explicita la ajenidad con la cual se acerca a la cultura materna, o sea, a la propia. Una de las primeras escenas con las que debía contar la película, según el guión original transcripto en el libro, era la siguiente:

Sobre el escenario kitch y berreta de un club nocturno con escenografía 'latina', Amanda, una atractiva mujer de 30 años, vestida de 'amante latina', al estilo de una Carmen Miranda, hace un número de strip-tease al compás de música tropical. Andrés off: No. Ésta no es Mamá. Es Amanda. Pero hablar de Mamá es hablar de recuerdos y en los recuerdos se mezcla todo. Y quién sabe qué recuerdo tiene que ver con cuál otro... (Firbas - Meira Monteiro 2006, 114).

A pesar de que esta escena no se incluye finalmente en la película, la intención de comenzarla con una figura exótica como la de Carmen Miranda, epítome de la perspectiva turística y orientalista que aborda al otro como una mujer y un objeto sexual, es significativa y muestra su deseo de exponer el problema de un modo casi grosero y brutal. Al llegar a la India, descubre en sí mismo esta mirada: “(...) me sentí completamente ajeno, pez fuera del agua, peor que el peor turista occidental" (Firbas - Meira Monteiro 2006, 136). Pero al producirse sobre el propio yo, esta mirada se vuelve clisé de sí misma y se transforma en perspectiva crítica.

A medida que su viaje transcurre, Di Tella va hurgando en su propio pasado y reevalúa su relación con la India hasta el momento. Se pregunta por qué su madre nunca le habló de su país. Su método de análisis lo lleva a reconocer la sorpresa con la que, en un momento de su vida, descubrió su propia negritud: "Cuando supe que era negro fue como si me inocularan un veneno, la conciencia de no ser blanco, la 'impureza' de mi sangre, que nunca me abandonó" (Firbas - Meira Monteiro 2006, 132). O sino: "No me gustaba ser identificado como hindú. ¿O sea que yo también era racista?" (Firbas - Meira Monteiro 2006, 127). Así, en contra de una mirada aparentemente progresista y condecendientemente multiculturalista, Di Tella habla de su propio racismo y paradójicamente- insistiendo sobre el poder con el cual calan los prejuicios raciales, lo revela como una estructura profundamente arraigada, incluso en su propio yo.

Pero esta constatación no se detiene en el terreno puramente privado, pues, como dice Di Tella en sus comentarios, él llega a la India por un rodeo que lo saca de su historia personal y le da a lo negado de su vida (la identidad hindú) un estatuto casi oficial o nacional. En el símbolo de identidad nacional, el gaucho, Di Tella encuentra (al igual que en su propia identidad) una herencia hindú: "También hace falta decir que llegué a la India a través del gaucho" (Firbas - Meira Monteiro 2006, 127). Se trata de la historia de Ramachandra, que también es de la India pero que vive en la Patagonia y que es el hijo adoptivo de Ricardo Güiraldes, autor de Don Segundo Sombra. Toda una parte de la película está dedicada a contar el viaje de Di Tella a la Patagonia y las conversaciones que tiene con Ramachandra.

Este le cuenta que hurgando y desempolvando los archivos de Güiraldes, descubrió una cantidad de documentos y notas de trabajo de su padre que relacionan el gaucho con el gurú hindú, permitiendo arrojar 
nueva luz a la lectura de esta novela de consolidación de la identidad nacional. En una escena de la película, Ramachandra lee el famoso capítulo de la doma del caballo en esta clave.

Es decir, así como Di Tella descubre en sí una identidad hindú, también descubre en el gaucho argentino una identidad "negra". Más allá de la veracidad de esta historia, lo interesante de ella es que el gaucho como símbolo de la identidad y de la literatura "nacional" adquiere un estatuto impostado y aparece como deudor de una tradición extranjera, negra y -para la mentalidad europeizante argentina- con un grado de subalternidad mayor que la propia. Así, el archivo de Güiraldes (simbólicamente importante en un archivo literario nacional) se revela -como el archivo personal de Di Tella- como una ficción que oculta políticas racistas. Por supuesto,

Ramachandra finalmente no lo hereda a Güiraldes ya que los parientes de éste lo consideran un impostor o un intruso. En una conversación que aparece en la película, uno de los descendientes de Güiraldes le dice a Di Tella que Ramachandra era "un cuervo en una bandada de pájaros blancos" y Di Tella agrega, estableciendo un lazo entre su propia identidad y la identidad nacional: "igual que yo." Ahora bien, a pesar de que el viaje que emprende Di Tella en Fotografías podría pensarse como una variación del tradicional viaje etnográfico, pues la primera persona viajera lo hace hacia un otro idiomático, geográfico y cultural -y no se deja de subrayar esta "extranjeridad" con respecto a la cultura otra-, el suyo es un caso particular en el cual la mirada turística y tradicional se complejiza pues la cultura otra es, al mismo tiempo y sin dejar de ser exótica, propia. De este modo, la etnografía pasa a ser una suerte de autoetnografía y la separación del objeto de mirada turística y el sujeto que se propone a estudiarlo queda abolida y, simultáneamente, diferenciada: yo soy el intruso dentro de mi propia cultura (en donde el enunciado vale para los dos casos: cuando la propia cultura se refiere a Argentina así como cuando se refiere a la India)6. De este modo, si bien la película muestra las contradicciones de una mirada orientalista o exotizante, también señala la exterioridad que comportaría una crítica progresista hacia ella, al señalar la inevitabilidad de su adopción. Este acercamiento a una ajenidad a través de lo propio, o, a lo propio como si se mirara desde afuera, establece un doblez en la forma de pensar la diferencia cultural, racial o nacional. La película no deja de decir una y otra vez "soy extranjero en mi propia patria" o "ese idioma que no entiendo es en realidad mi lengua materna". La propia situación identitaria del director (y personaje) queda así en un territorio sin lengua ni patria.

Sin embargo, al exponer los deseos y los miedos más primarios de su protagonista sin ningún tipo de condescendencia o de progresismo (¿yo también era racista?), este film no establece ningún mensaje efectivo o didáctico y no obtiene ninguna funcionalidad social.

En este movimiento, el proyecto artístico de Di Tella cuestiona la distinción entre sujeto y objeto etnográfico; entre el sujeto que filma y el objeto de documentación; entre el archivo supuestamente objetivo y el sujeto que lo estudia, o entre aquel que es nativo y el que es extranjero. Pero estos franqueamientos no se hacen de un modo puramente formal sino que surgen de una redistribución de lugares, de alteraciones de las jerarquías epistemológicas y competencias: yo hablo del otro pero ese otro soy yo. Se construye así un tipo de subjetividad en la cual se funda la posibilidad de crear una obra documental vacilante en cuanto la propia definición que se le da a la documentalidad y a su estatuto epistemológico.

Es decir, es el cuestionamiento de la autenticidad del archivo (tanto el personal como el nacional) y la solidaridad que este cuestionamiento mantiene con una concepción de la subjetividad como algo opaco, los que permiten que el discurso documental en el cual el film se desarrolla se encuentre minado en sus propios fundamentos. Es 
en este punto en el que la categoría de ficción adquiere una relevancia fundamental para el proyecto del documental mismo.

2. Construir un archivo para el futuro: hacer ficción no consiste en contar

historias7

Di Tella cuenta que recibe de parte de su padre una caja con fotografías familiares que sirve como disparador del viaje y de la película. El film recorre estas fotos enfocándolas recurrentemente en primeros planos, de modo que pasan a ocupar la totalidad de la pantalla mientras el propio director las comenta, apuntando con el dedo a los personajes de los que se habla. Así, la película se desarrolla como si fuera una exhibición fotográfica o como un álbum de fotos comentado, característica que se enfatiza en el título y que le quita su carácter fílmico para darle una fijeza más apropiada para una obra colgada en un museo o para un libro de arte8. Como ya se ha dicho, la película además viene acompañada de un libro, llamado Conversación en Princeton: cine documental y archivo personal, en donde, luego de una larga conversación sobre la película, Di Tella hace públicas sus notas en borrador y una suerte de guión previo a su filmación. Retomando lo que señala Daniel Link, este libro puede pensarse más que como un complemento de la película, como su "exceso", indicando que hay algo que es imposible de recuperar por entero, una memoria que está más allá de la memoria familiar e incluso -como ya he dicho- de la memoria nacional9.

Por otro lado, con el libro la película tiene un plus que podríamos llamar "literario" que incrementa su deslizamiento hacia el exterior de sí misma, obligándonos a ser espectadores y lectores de un modo simultáneo, enfrentándonos a un objeto cultural múltiple, sin bordes definidos ni límites fijos10. Este cuestionamiento de los bordes entre diversas esferas artísticas redunda en un cuestionamiento de los límites del marco principal de esta película: lo documental. Se trata de algo que excede a la obra misma, un límite que se materializa como una pérdida en la capacidad de archivar: un olvido, un documento irrecuperable o la ausencia de pruebas que puedan testimoniar un recuerdo o un sueño.

Hay un resto disfuncional en relación a la intención de documentar la propia vida y -al mismo tiempoabsolutamente necesario para ser fiel a la verdad que se pretende obtener en esta documentación. De un modo paradójico, el film parecería decir que, sin este exceso afectivo que desborda los límites del documento o del archivo, no se podría lograr el objetivo de hacer un filme documental.

En Fotografías se observa un procedimiento que es ilustrativo de esto pues las fotos reales y las filmaciones en súper 8 -provenientes de viejos archivos familiares- se superponen con otras escenas que Di Tella recuerda o fantasea sobre su madre, pero para las cuales no tiene material de archivo: ni fotos ni películas. En estos casos, el documento es reemplazado por filmaciones ficcionales en las que una actriz simula el recuerdo o inclusive un sueño que el director tiene con su madre, muchas veces dándole a la filmación contemporánea una pátina que simula la del documento histórico. Este procedimiento le permite crear retrospectivamente una experiencia o una memoria inexistente y construir -como quiere Derrida- un archivo futuro, un documento ficticio que funcionará, a partir del propio film, como una simulación del recuerdo. Ante la imposibilidad de rescatar del olvido aquello que 
no sucedió, los recuerdos y los documentos que los testifican se inventan, creando una ficción dentro del universo documental11.

El valor del olvido o de la falla archivística no está en señalar un sublime irrepresentable sino en marcar la laguna que permite que la ficción ocurra. Es decir, es desde el señalamiento de una pérdida, de un agujero en el archivo, en lo identitario o en la capacidad para guardar y memorizar, que surge la misma pérdida como posibilidad subjetiva y como condición de posibilidad de lo ficticio. La ficción adquiere -entonces- ciertas características particulares, pues no toma la forma de construcción verosímil (enredo, épica, drama o intriga) sino que es aquello que viene a darle voz a un exceso afectivo que no puede ser documentado de otra manera.

Este modo de entender la categoría de ficción puede quizás comprenderse mejor remitiéndose a ciertas formulaciones teóricas sobre el cine documental y sobre la fotografía.

En un ensayo en el que analiza un filme Chris Marker, Jacques Rancière propone que en el trabajo que realiza el filme documental en tanto género se puede ver cómo la categoría de ficción se reduce a "su esencia":

Le film documentaire peut donc isoler le tràvail artistique de la fiction en le dissocient de ce a quoi on l'assimile volontiers: la production imaginaire des vraisemblances et des effets de réel. II peut le ramener à son essence: une manière de découper une histoire en séquences ou de montrer des plans en histoire, de joindre et de disjoindre des voix et des corps, des sons et des images, d'etirer ou de resserrer des temps. (Rancière 2001, 203)

Es decir, la disociación del concepto de ficción de la construcción de una verosimilitud - cuya correspondencia pertenece según Rancière a una poética clásica- nos lleva a pensarlo de un modo tal que lo retrotrae a su sentido etimológico: "Fingere ne veut pas dire d'abord feindre mais forger" (202). En otros ensayos en los que vuelve sobre el mismo asunto, Rancière insiste en que el trabajo de la ficción "no consiste en contar historias" (Rancière 2010,102), y en que su definición no debería basarse en la oposición entre "la realidad y sus apariencias" (102), sino más bien en la posibilidad de ver lo mismo de un modo diferente o de construir otras formas de dar sentido. En esta misma línea podría entenderse la hipótesis de Josefina Ludmer acerca de la definición de la ficción en la época de la autonomía de la literatura a partir de una relación específica entre "la historia" y "la literatura", en la cual ambas esferas mantienen su especificidad y separación:

La narración canónica, o del boom [Cien años de soledad, por ejemplo] trazaba fronteras nítidas entre lo histórico como "real" y lo "literario" como fábula, símbolo, mito, alegoría o pura subjetividad, y producía una tensión entre los dos: la ficción consistía en esa tensión. La "ficción" era la realidad histórica [política y social] pasada [o formateada] por un mito, una fábula, un árbol genealógico, un símbolo, una subjetividad o una densidad verbal.

\section{(Ludmer 2007)}

Por lo contrario, si pensamos la ficción fuera de una "poética clásica" o fuera de la autonomía, se hace necesario tener en cuenta la imposibilidad de separar estas esferas. En relación a esta concepción sobre la ficción y a su íntima relación con el trabajo documental, resulta iluminador recurrir a un ensayo del fotógrafo catalán Joan Fontuberta llamado, justamente, "Ficciones documentales". Fontcuberta deconstruye allí lo que califica como el "discurso hegemónico de la modernidad fotográfica”, según el cual la esencia de la fotografía residiría en su capacidad de significación indicial y en su "voluntad de testimonio" (104). Según Fontcuberta, a pesar de que a lo largo de la historia de la fotografía ha prevalecido una intención descriptiva, esta misma intención se ha valido, en muchas ocasiones, de lo que él califica como una "trampa", ya que involucra la urdimbre de una ficción. A 
través del análisis de uno de los primeros daguerrotipos conocidos -la vista del Boulevard du Temple (fechado en 1838)- y de una imagen de Hippolyte Bayard de 1840 en el que el autor de la foto se retrata a sí mismo simulando haberse suicidado, Fontcuberta descubre -"en el mismo nacimiento de la fotografía" (104)- la trampa que cuestiona, al mismo tiempo que instituye, el estatuto de la foto como documento. La imagen de Daguerre es doble: dos tomas efectuadas en el mismo día. En una de ellas se ve el boulevard completamente vacío en un horario en el que debería estar lleno de gente. Fontcuberta explica que esta incompatibilidad entre la realidad y la percepción de la cámara ocurre porque el tiempo de exposición que requería la obtención de la imagen en ese entonces no permitía captar ningún objeto en movimiento. La solución de Daguerre a este problema -que se ve en la segunda toma- es la de utilizar actores e introducir un limpiabotas con su cliente sobre la vereda. De esta manera, engañando al espectador a través de una actuación, consigue una imagen más fiel a la realidad. Ahora bien, según señala Fontcuberta, mientras "el estatuto ficcional de ese daguerrotipo presupone que la intervención en la escena pasa desapercibida al espectador" (107), en el caso de la imagen de Bayard, la simulación de su propio suicidio "no esconde la naturaleza ficcional de la imagen" (108). Surge entonces, "otro tipo de ficción" (109), que me interesa particularmente para pensar en relación al modo en el cual surge la ficción en Fotografías:

La podríamos denominar ficción lúdica o ficción artística, categorías que se caracterizarían frente a la ilusión cognitiva y a la manipulación, en que se anuncian siempre como ficción, no camuflan su naturaleza de simulación.

La ficción artística no es que se oponga a lo verdadero, sino que se opone tanto a lo verdadero como a lo falso (entendido lo falso como error o mentira). Tampoco se opone al discurso referencial y realista sino que coloca al referente entre paréntesis. No afecta la verdad o falsedad de un enunciado, sino a nuestra facultad de creer, o sea, a nuestra facultad de adherirnos a proposiciones que consideramos verdaderas (lo sean o no) (Fontcuberta 109, el subrayado es mío).

La ficción artística o lúdica, entonces, correspondería a un tipo de simulación de un documento que no esconde su naturaleza ficcional. Así, si según Rancière en el cine documental podemos encontrar la ficción en un estado de "pureza", a través del ensayo de Fontcuberta se ve muy claro cómo en el nacimiento de la fotografía y, por lo tanto, en el origen mismo del documento -entendido con mayúscula- se encuentra una ficción. Sin embargo, en ambos planteos se rechaza la idea de que por tratarse de una ficción su valor de verdad disminuya. Por lo contrario, como dice Fontcuberta, la "ficción artística" coloca al referente "entre paréntesis" y promueve nuevos modos de colocarse ante la obra.

Quizás es en este sentido que puede entenderse la afirmación de Di Tella según la cual en sus filmes documentales le interesa exponer el "fracaso del proyecto documental" (Firbas - Meira Monteiro 2006, 42), en donde "documental" aquí debería leerse como sinónimo de "discurso objetivo" o "testimonial"; como un género con un propósito informativo y didáctico, con un fin moral o de denuncia. En un texto llamado "La palabra documental", Di Tella alude al rechazo que le provoca la palabra "documental" y a la posibilidad de pensarla de un modo diferente:

No me gusta la palabra documental. Es como el club de Groucho: "No deseo pertenecer a un club que acepta entre sus socios a alguien como yo". 
El vocablo documentalista trae a la mente un auxiliar administrativo que revisa expedientes en una dependencia municipal. $\mathrm{O}$, en el mejor de los casos, una especie de cazador filantrópico que avista ballenas (o indígenas) con un teleobjetivo. En algún sentido, el documental parece ubicarse en un polo opuesto al del cine. "Cine" evoca toda una sucesión de palabras que empiezan con f de ficción: fantasía, fábula, fascinación, frenesí, fantasma, felicidad, film. «Documental», en cambio, trae otra serie de asociaciones, términos que empiezan con t de testimonio: tema, trabajo, tesis, teoría, tarea, tristeza... tedio. Sin embargo, ay, hago documentales. Pero creo que el documental, sin perder la fuerza de lo real, también puede aspirar a esa dimensión cinematográfica propia de la ficción. Es decir, me gusta pensar que hago películas. (Di Tella, 2012)

Así como en el concepto de "ficción artística o lúdica" propuesto por Fontcuberta se pone el referente entre paréntesis permitiendo un acceso a la verdad a través de la simulación, este segundo modo de entender lo documental permite que no se pierda "la fuerza de lo real", pero que se acceda, simultáneamente, a una dimensión que aparece asociada a cierto más allá del documento mismo y que Di Tella identifica con una especificidad del cine: "hago películas". Se trata entonces de una práctica más relacionada con el exceso, con el deseo o con el arte ("fantasía, fábula, fascinación, frenesí, fantasma, felicidad, film”) que lo que a primera vista entendemos cuando escuchamos, según él mismo nos dice, la palabra "documento". La opción documental entendida en este sentido desborda el puro testimonio y la "tristeza, el trabajo o el tedio" asociados con la pretensión de objetividad. Se trata de una suspensión moral que cancela cualquier tipo de expectativa previa acerca de lo que debe ser tal o cual práctica artística o, en este caso preciso, de lo que debe ser el cine documental12. Pero la libertad que otorga el documental no es únicamente en relación a la supuesta objetividad del "documento" sino también en relación a la estructura que brindaría la ficción diseñada desde una poética clásica: la construcción de una verosimilitud que garantiza una separación clara entre "literatura" e "historia". En el mismo texto recién citado, Di Tella habla de la diferencia entre cine de ficción y documental en estos términos:

Se ha dicho que en la ficción se escribe antes de filmar (el guión) mientras que en el documental se escribe después de filmar (el montaje). Se trata sin duda de una simplificación. Yo creo, más bien, que cualquier distinción remitiría a las diferentes tradiciones, o "familias", de películas. Esa caracterización ayuda, de todos modos, a explicar la potencia actual de la corriente documental dentro del cine argentino. La ficción depende demasiado de la imaginación del que escribe el guión, de sus limitaciones, de sus prejuicios, incluso de los estereotipos genéricos de un argumento. La escritura de un documental, del buen cine documental, refleja la experiencia, siempre singular, siempre imprevisible, de una investigación, de un rodaje, de un encuentro con el mundo. El resultado, si no ha de traicionar el proceso, no puede ser otra cosa que único. En el documental están las historias que un guionista difícilmente pudo imaginar. (Di Tella, 2012)

Esta improvisación que señala Di Tella como propia del cine documental y como algo opuesto al cine de ficción, en el que el guión se escribe antes de filmar, coincide con una narrativa que no esconde el proceso mismo de construcción y en la que se sigue un tipo de imaginación en el que surge algo que no se hubiera podido prever dentro de la estructura ficcional clásica, algo que se escapa.

Es así que a partir del "fracaso" del "proyecto documental" entendido como puro documento surgen nuevas posibilidades para el cine, pero también para la literatura o para cualquier otra forma narrativa. "Ficción documental" sería entonces un modo de narración o de imaginación en el que la ficción surge sin plan, como colándose entre los resquicios del archivo pero en íntima relación a este y al documento. Se trata de un "fuera de campo" que, como dice Jean-Louis Comolli, cuestiona la noción de que todo es pasible de ser archivado, procesado o pasible de transformarse en imagen y relaciona la obra con el "cine" (entendiendo este concepto 
como lo hace Di Tella en el pasaje arriba citado pero también como lo entiende Comolli, es decir, como aquello que se opone al espectáculo)13.

Pareciera, según esta idea, que el cine documental y la literatura que se le parece, tienen una capacidad para crear un espacio de redistribución de lo sensible, de inoperatividad, o una "zona ciega" (Montaldo) que abre nuevas posibilidades para contar una historia. Se trata de un sitio que surge desde un revés, como un recuerdo inventado o una desmemoria que se transforma, al convertirse en texto o en imagen, en contra-memoria, en la medida en la que escribe nuevamente algo de la historia y permite -como dice Rancière a propósito del trabajo de la ficción- "un paisaje nuevo de lo posible" (103).

En uno de los textos que acompañan la película, Di Tella cuenta una conversación que tuvo con el escritor de origen indio Naipaul, en la cual le preguntó por su viaje a Londres en los años cincuenta -época en la que también estaban allí su padre y su madre: una pareja interracial-. Naipaul le cuenta que en ese momento él no estaba interesado en la ola inmigratoria del momento y se lamenta por haberse perdido "el fenómeno humano y social tan extraoridinario que estaba delante de sus ojos" (Firbas - Meira Monteiro 2006, 109). A partir de esto, Di Tella comenta:

Eran los comienzos de ese gran movimiento de personas que hoy se ve reflejado en la población de cualquier ciudad europea o norteamericana. Ya no se trataba simplemente de europeos que se mudaban a América, como pudo ser la inmigración de principios de siglo en Estados Unidos o incluso la Argentina, sino de gente de todos los continentes y todas las razas que iba a todas partes. Era el principio del presente, dijo Naipaul (Firbas - Meira Monteiro 2006, 110).

A partir del comentario de Naipaul, en el cual se subraya un anacronismo, Di Tella propone un modo de entender el pasado en el cual este no se erige como historia cerrada, como origen o autenticidad. Es que, según él demuestra en su film, los recuerdos también se inventan y son esos los que servirán como archivos futuros, produciendo un resto afectivo, excesivo a lo histórico o a lo estrictamente documental. Es esta perspectiva genealógica que deja un lugar para que el afecto se infiltre, y para que se pueda leer el pasado como un resultado de lo que ocurre en el presente, la que le da a la obra su potencia crítica y le permite producir una intervención en su propio mundo contemporáneo.

\section{Notas}

1. Esta nueva configuración cultural -y los desafíos que ella presenta para los críticos culturales- ha sido pensada desde diversos ángulos en la crítica latinoamericana. Josefina Ludmer habla de una literatura posautónoma y de un nuevo modo de imaginación para el presente. Según ella, las nuevas escrituras entran y salen de la realidad a la literatura y viceversa, y se constituyen en esa "ambigüedad" en donde ya no se puede hablar de "realidad" o "ficción" sino de "realidadficción" (Ludmer, 2010). Jean Franco habla de la caída de la ciudad letrada (Franco, 2002); Néstor García Canclini habla del "arte fuera de sí" (Canclini, 2010); Florencia Garramuño de una obra "estriada por el exterior" (Garramuño, 2009) y Reinaldo Laddaga se propone indagar qué formas son las que corresponden a una cultura no disciplinaria de las artes (Laddaga, 2006). Según éste crítico, el escenario artístico contemporáneo presenta un cambio tan drástico y produce una modificación tan 
importante en cuanto a la concepción de la literatura misma, que puede compararse al del momento de constitución de la literatura moderna (Laddaga, 2007).

2. Recordemos, entre otras tantas, la clásica afirmación de Christian Metz: "todo filme es un filme de ficción" (Metz, 1977) o la archicitada afirmación de Godard según la cual todas las películas, hasta las de ficción, son documentales de sí mismas. En casi todos los textos que intentan definir de un modo teórico el cine documental se presenta este problema.

3. Más adelante me ocuparé de precisar qué entiendo por "ficción clásica".

4. La frase "soy negro" que se repite una y otra vez bajo diferentes formulaciones en la película cita, evidentemente, la clásica película de Jean Rouch. Moi, un noir (1958), de la cual he tomado el título para esta sección. Evidentemente, el film de Di Tella pretende de algún modo homenajear el documental de Rouch o al menos situarse dentro de una tradición de "cinéma vérité" que Rouch inicia y que, según el propio Di Tella, es paradigmática en cuanto a la relación del documental con la ficción: "Para Rouch, lo que revela un documental no es "la realidad" en sí sino la realidad de un especie de juego que se produce entre unas personas delante -y detrás- de una cámara. Es por eso que Godard, gran admirador de Rouch, señaló a propósito de Yo, un negro que 'todo gran film de ficción tiende hacia el documental, así como todo gran documental tiende hacia la ficción'” (Di Tella "El documental y yo" en Firbas - Meira Monteiro 2006, 160).

5. El libro al que me refiero es Conversación en Princeton. Luego hablaré en él de modo más detallado.

6. En relación al gesto "autoetnográfico" y su vínculo con un proyecto documental, ver Catherine Russel, 1999.

7. La segunda parte de este subtítulo está tomado de una frase de Jacques Rancière (Rancière, 2010, 102).

8. Este aspecto es subrayado por Marcela Visconti (2011): "La idea de estar mirando fotografías es reforzada por el sonido intermitente de un proyector de diapositivas en sincronía con sucesivos inserts negros que van puntuando el desfile de las imágenes".

9. Dice Daniel Link: "Esos textos (apuntes en una libreta, reflexiones más articuladas) son necesarios al proyecto que Di Tella encara no tanto porque lo expliquen (ésa sería su característica más débil) sino porque señalan su exceso respecto del documental: la propia memoria familiar, la que Di Tella está interrogando, es, al mismo tiempo, un viaje hacia el pozo sin fondo de las inquietantes preguntas a propósito de qué significa ser argentino y qué, ser moderno" (Link, 2006).

10. El blog que escribe Di Tella se llama también "Fotografías", de tal modo que se establece una conexión entre este blog con la película y el libro.

11. Como ya se ha dicho, hay muchos films documentales que utilizan escenas ficcionales y que se ubican en el límite entre documentalidad y ficción. Sin embargo, no en todos los casos la ficción surge como invención de recuerdos o simulación de un documento de archivo.

En Passaporte húngaro (2003), Sandra Kogut realiza un procedimiento similar al de Di Tella. Brasileña de nacimiento, Kogut decide tramitar un pasaporte de la nacionalidad de sus abuelos, judíos expulsados de Hungría 
en la inminencia de la Segunda Guerra, y filma el proceso que lleva su obtensión. El documento concreto, el pasaporte de la abuela en tanto documento personal e intransferible y, al mismo tiempo, oficial y público, sirve como disparador y título y como vértice para superponer registros y archivos públicos -como el del puerto en el que Kogut busca los registros de la llegada del barco de sus abuelos a Brasil-, y privados -como las fotos y las conversaciones filmadas con diversos miembros de la familia.

Al igual que en la película de Di Tella, ante la falta de documentación que ilustre el proceso de migración de sus abuelos, Kogut coloca imágenes de estaciones de trenes y de puertos, de partidas y de llegadas, filmadas en súper 8 en el presente, pero simulando, por el tipo de cámara, imágenes de archivo y creando cierta atmósfera poética y ficcional. Así, entre medio de las charlas de Kogut con su abuela y con funcionarios estatales, es decir, en un contexto de entrevistas que nos recuerdan que estamos ante un documental, con la infiltración de las imágenes ficcionales, el film confunde diversos registros artísticos y dos temporalidades, pues con ellas se construye un pasado y se comenta, simultáneamente, sobre la situación migratoria de la propia directora y sobre su regreso al país de origen como extranjera.

12. En este mismo sentido "excesivo" es que debe pensarse el gesto autobiográfico en los films de Di Tella, como cancelando una expectativa previa de lo que debe o no debe ser una práctica artística: "Es muy difícil en el discurso del documental renunciar a esa idea de la utilidad (...) Las películas caseras serían como el colmo de lo que no tiene interés ni utilidad pública. Por supuesto yo creo que es al revés, que hacer público lo privado es de gran utilidad pública. Pero cuesta que esa idea sea aceptada. Siempre hay como un reproche, como si en el documental lo privado fuera menos serio, irresponsable, narcisista" (Firbas - Meira Monteiro, 2006, 121). Este gesto de darle una "utilidad" o -podríamos decir- sentido a aquello que parece ser aparentemente sin sentido, se ve en la noción de que el documental autobiográfico puede ser un acto de responsabilidad: "An autobiographical documentary is a courious act of responsibility. I assume responsibility for this story. I answer for it with my life. I answer for my ideas about film and art (and life) with my own life. I lay down my own body there, with no surrogates. And of course, in so doing, I confess my limitations" ("The Curious Inicident of the Dog in the Nightime", 36). Esto podría pensarse en relación a las observaciones que propone Judith Butler en Giving an account of oneself.

13. "Mostrar que no se puede mostrar todo es poner al espectador en un lugar real con respecto a la ilusión de totalidad del Espectáculo. En el cine se trata de mostrar, contra el espectáculo, que el mundo no es 'omnivisible', que ver es ver más allá del encuadre, ver que hay un fuera de campo que no está encuadrado. El fuera de campo no es únicamente lo que el encuadre oculta al mostrar, es todo lo que se mantiene al margen de la posibilidad de ver, al margen del lugar del espectador, lo que no constituye imagen (y por lo tanto no hace espectáculo), el fuera de campo de toda imagen" (Comolli, 127).

Bibliografía

Butler, J. (2003). Giving an Account of Oneself. New York: Fordham University Press.

Comolli, J. L. (2010). Cine contra espectáculo. Seguido de Técnica e ideología (1971-1972). Buenos Aires: Manantial. 
Cowie, E. (1999). “The Spectacle of Actualtiy” en Gaines, J. and Renov, M. Eds. Collective Visible Evidence. Minneapolis: University of Minnesota Press.

Chanan, M. (2007). The Politics of Documentary. London: British Film Institute.

Derrida, J. (1995). Archive Fever: A Freudian impression. Chicago: University of Chicago.

Di Tella, A. (2012). "The Curious Incident of the Dog in the Nighttime" en Lebow, A. (ed.) The Cinema of Me. The Self and Subjectivity in First Person Documentary. New York: Columbia University Press.

“La palabra documental”. Página 12. Jueves 28 de junio, 2012. Disponible en:

http://www.pagina12.com.ar/diario/suplementos/espectaculos/5-25666-2012-06-28.html (último acceso junio 2014).

Firbas, P. y Meira Monteiro, P. (eds.) (2006). Conversación en Princeton. Andrés Di Tella: cine documental y archivo personal. Buenos Aires: Siglo XXI.

Fontcuberta, J. (2010). “Ficciones documentales” en La cámara de Pandora. La fotografía después de la fotografía. Barcelona: Gustavo Gili.

Franco, J. (2002). The Decline and Fall of the Lettered City. Cambridge, Mass.: Harvard University Press.

García Canclini, N. (2010). La sociedad sin relato. Buenos Aires: Katz.

Garramuño, F. (2009). La experiencia opaca. Buenos Aires: Fondo de Cultura Económica.

Ishizuka, K. y Zimmermann, P. (eds.) (2007). Mining the Home Movie: Excavations in Histories and Memories. Berkeley, CA: University of California Press.

Laddaga, R. (2006). Estética de la emergencia. Buenos Aires: Adriana Hidalgo Editora.

Laddaga, R. (2007). Espectáculos de realidad: ensayo sobre la literatura latinoamericana de las últimas dos décadas. Rosario: Beatriz Viterbo.

Lebow, A. (ed.) (2012). The Cinema of Me. The Self and Subjectivity in First Person Documentary. New York: Columbia University Press.

Link, D. (2006). Blog linkillo. Disponible en: http://linkillo.blogspot.com/2006/08/librosrecibidos_18.html (consultado en agosto del 2013) Ludmer, J. (Julio 2007). "Literaturas posautónomas”. Ciberletras. Revista de crítica literaria y de cultura. 17.

. (2010). Aquí América Latina. Una especulación. Buenos Aires: Eterna Cadencia.

Metz, C. (1977). Le signifiant imaginaire: psychanalyse et cinema. Paris: Union génerale d'editions.

Montaldo, G. (2010). Zonas ciegas. Populismo y experimentos culturales en Latinoamérica. Buenos Aires: FCE. 
Rancière, J. (2001). La fable cinématographique. Paris: Le Seuil.

(2010). El espectador emancipado. Buenos Aires: Manantial.

Renov, M. (2004). The Subject of Documentary. Minneapolis: University of Minnesota Press.

Russel, C. (1999). Experimental Ethnography: The Work of Film in the Age of Video. Durham, NC: Duke University Press.

Visconti, M. (2011). "El principio del presente". Revista afuera. 10, mayo. Disponible en:

http://www.revistaafuera.com/articulo.php?id=139\&nro=10 (consultado en noviembre de 2011)

Abstract:

One of the most remarkable features of contemporary literature is the ambivalence in the definition of its fictional statute. In most of the novels and stories that have been published in the last decades fiction is, al least, ambiguous. In those texts, chronicle and autobiography, the reflection on the own writting process or the essay style merges with fictional narrative fragments producing a questioning of the fictional statute within literature in itself. In this article we affirm that documentary cinema is an appropriate site (a laboratory) to think the transformation of fiction in contemporary art. After the analysis of the documentary Photographies (2006) by Andrés Di Tella, certain procedures relating to how fiction arises inside are investigated. The expectation is that this research will serve as a theoretical basis for thinking the transformations that not only fiction category in the documentary film but also, more broadly, in other contemporary art forms, such as in literature.

Key words:

documentary cinema - contemporary art - ambiguous fiction - literature - narrative - chronicle - autobiography.

Resumo:

Uma das características mais notórias da literatura contemporânea é a ambivalência na definição de seu estatuto ficcional. Em muitos dos textos publicados nas últimas décadas e que se qualificam como novelas ou contos, a ficcionalidade resulta ambígua.

Trata-se de textos nos quais a crônica, a autobiografia, a reflexão sobre o próprio processo de escritura ou a escritura ensaística se entrelaçam com fragmentos narrativos ficcionais, produzindo um questionamento do estatuto da ficção dentro da literatura mesma. Neste trabalho se afirma que o cinema documental resulta um sítio propício -um laboratório- para pensar a transformação que sofre o conceito de ficção na arte contemporânea. A partir da análise do documental Fotografias (2006) de Andrés Di Tella, analisa-se alguns procedimentos em relação ao modo como surge a ficção no seu interior. A expectativa é que essa indagação sirva com base teórica para pensar as transformações que sofre categoria de ficção não somente no cinema documental senão também, mais amplamente, em outras manifestações artísticas contemporâneas, como por exemplo, na literatura. 
Palavras chave:

cinema documental - arte contemporânea - ficcionalidade ambígua - literatura - narrativa - crônica autobiografia.

Un paisaje nuevo de lo posible. Hacia una conceptualización de la "ficción documental" a partir de Fotografías, de Andrés Di Tella fue publicado de la página 87 a página101 en Cuadernos del Centro de Estudios de Diseño y Comunicación $N^{\circ} 60$ 